\title{
PERAN ORANG TUA MENGATASI MASALAH REMAJA PENGHIRUP LEM
}

\author{
Amirah Diniaty, Mahdar Ernita, Afrida, Dody Leyno Amperawan, \\ Emilia Susanti \\ Universitas Islam Negeri Sultan Syarif Kasim Riau, Indonesia \\ Amirah.diniaty@gmail.com
}

\begin{abstract}
This paper describes the efforts of parents in addressing the behavior of teenagers inbale glue or known by the term "ngelem". This research-based service location is in the village of Kualu Nenas border city of Pekanbaru of Riau Province and Kampar. Methods used participatory action research. The data are collected with interviews on parents and village officers followed up with mentoring parents deal with Teen inhalent. The results showed that parents have not been concerned and considers paltry teenage habit of inhaling glue. They did not aware of the bad consequences of spending babits of inbaling glue. We discuss with parent and trained them the right to behave to their child so that their teens stop inhaling glue. Need for awareness of the community to conduct prevention so that teenagers can stop the behavior of this glue, since inhalation impact the physical, psychic and social teenagers.
\end{abstract}

Keywords: Parent, Teenager, Glue Inhaler (Ngelem)

\section{PENDAHULUAN}

Lem adalah benda yang sudah dikenal oleh setiap orang sebagai alat perekat. Fungsi dari lem merekatkan suatu benda pada satu media tertentu, sesuai dengan keperluan masing-masing. Selain berfungsi sebagai perekat, ternyata zat yang ada di lem, dihirup sebagian remaja untuk kesenangan. Zat yang dihirup dikenal dengan istilah toluene adalah hidrokarbon aromatik yang digunakan secara luas dalam industri dan juga sebagai pelarut. Toluene dapat diserap ke dalam tubuh melalui proses menghirup, pencernaan, dan kontak dengan kulit.

Jenis lem merek cap kambing, Aica Aibon yang digunakan remaja ternyata mengandung zat adiktif yang (inhalen) yaitu Asam Lisergat Dietilamida disingkat ASD atau Lysergic Acid Diethylamide/LSD) yang disebut juga "Acid". Zat ini ditemukan oleh Albert Hoffman (1906-2008), seorang ahli kimia asal Swiss. ALD atau acid adalah obat psikedelik semi sintetik dari golongan ergolin, terkenal karena efek psikologisnya yang meningkatkan kemampuan berpikir, visual/halusinasi baik dalam mata tertutup maupun 
terbuka, synaesthesia (kebingungan indera, misalnya: mendengarkan warna, melihat lagu), serta distorsi waktu. Apabila lem cair tersebut dihirup dalam-dalam, maka dapat memberi efek melayang sebagaimana dirasakan oleh pengguna narkoba.

Perilaku menghimp lem dikenal dengan istilah inhalen dalam kamus Bahasa Belanda memiliki makna kiasan yaitu ketika seseorang melakukan hal yang lebih baik daripada orang yang lebih baik sebelumnya. Inhalen juga digunakan dalam istilah kimia yang merupakan proses menghirup senyawa organik berupa gas pelarut yang mudah menguap. Dalam konteks ini istilah inhalen merupakan proses seseorang menghirup uap dari zat pelarut (thiner cat), uap lem, atau zat lainnya yang dapat menimbulkan perasaan melayang/mabuk.Senyawa ini biasa ditemukan dalam zat-zat yang mudah ditemukan remaja pada lem aica aibon, pelarut cat, tip-ex, bensin, pernis, aseton, dan sebagainya. Kebiasaan inhalen atau perilaku menghirup lem ini menjadi sangat mudah dan dapat dilakukan berulang-ulang karena harga lem yang cukup murah dan dijual secara bebas, dibandingkan narkotika seperti heroin atau ganja.

Efek yang ditimbulkan dari menghirup lem hampir mirip dengan jenis narkoba yakni menyebabkan halusinasi, sensasi melayang-layang dan rasa tenang sesaat meski kadang efeknya bisa bertahan hingga 5 jam sesudahnya. Akibat menghirup lem ini kadang-kadang remaja tidak merasa lapar meski sudah jamnya makan.Umumnya efek akut bahan ini serupa dengan inhalasi ether atau mitrous oxyda (obat anastesi/bius umum) yang berupa euphoria ringan, mabuk, pusing kepala tapi masih dapat mengontrol pendapatnya. Sesudah itu ia akan merasa bahwa dirinya tenang, namun pada akhirnya tidak jarang melakukan tindakan anti-sosial dan tindakan impulsif dan agressif. Hasil riset medis menunjukkan menghirup uap lem sangat berbahaya, sebab pada kadar tertentu bisa menyebabkan mati mendadak. Mohammad Isa (Kompasiana.com, Mei 2007) menjelaskan, resiko yang ditimbulkan dari penggunaan ALD/LSD adalah kerusakan pada sistem syaraf dan organ tubuh, seperti pernapasan, paru-paru dan otak, bahkan bisa menyebabkan kematian. Realitanya, remaja penghirup lem tidak menyadari bahaya tersebut, karena berbeda dengan jenis narkoba yang lain, dengan harga yang cukup murah, bahkan karena fungsi sebenarnya sangat bermanfaat, banyak yang tidak menyangka ada resiko berbahaya dibalik uap lem yang baunya cukup menyengat.

Secara psikologis, remaja penghirup lem adalah individu yang labil dan selalu ingin mencoba sesuatu yang baru. Emosinya tinggi akibat dari perubahan fisik dan kelenjar (Elizabeth B. Horlock, 1980: 212). Ciri-ciri remaja menurut Soesilowindradini (1990: 146- 
154) adalah "bersikap emosional, tidak stabil, banyak masalah, tidak disenangi orang dewasa, dan masa yang kritis". Sedangkan Elizabeth B. Horlock (1980: 207-209) mengatakan karakteristik remaja adalah masa remaja sebagai periode yang penting, masa peralihan, periode perubahan, usia bermasalah, masa mencari identitas, usia yang menimbulkan ketakutan, masa yang tidak terealitas, dan ambang menuju kedewasasaan.

Elida Prayitno (2006: 7) mengatakan mitos yang sering dipercaya tentang ciri remaja yang sedang berkembang adalah sebagai pemunculan tingkah laku yang negatif, seperti suka melawan, gelisah, periode badai, tidak stabil dan berbagai label buruk lainnya. Menurut Mc Candles, 1970; Dusek, 1977; Bezonsky, 1981 (dalam Elida Prayitno, 2006: 7) bahwa "remaja memperlihatkan tingkah laku negatif, karena lingkungan yang tidak memperlakukan mereka sesuai sesuai dengan tuntutan atau kebutuhan perkembangan mereka”. Misalnya, orang dewasa belum menerima remaja sebagai individu yang mandiri untuk menentukan atau mengarahkan diri sendiri.

Remaja memang memperlihatkan perilaku yang khas sebagai tanda bahwa mereka berkembang sebagai remaja yang normal. Selain itu Aulia Iskandarsyah (2006: 2-4) menyimpulkan ciri-ciri masa remaja yaitu, (1) Periode yang penting, (2) Masa peralihan, (3) Periode perubahan, (4) Usia bermasalah, (5) Masa pencarian identitas diri, (6) Usia yang ditakutkan, (7) Masa yang tidak realistis dan (8) Ambang dari masa dewasa. Kenakalan yang dilakukan remaja menghirup lem dapat memicu terjadinya berbagai jenis kenakalan sebagaimana dijelaskanJensen (dalam S.W Sarwono, 2001: 200), Sunarwiyati S. (Karimis dalam Padang Ekspres, 2009: 17), dalam bentuk perilaku yang (1) Menimbulkan korban fisik pada orang lain: perkelahian, perkosaan, perampokan, pembunuhan, (2) Korban materi: perusakan, pencurian, pencopetan, pemerasan, (3) Kenakalan sosial yang tidak menimbulkan korban di pihak lain: pelacuran, penyalahgunaan obat, serta hubungan seks di luar nikah, dan (4)Kenakalan yang melawan status misalnya mengingkari status anak sebagai pelajar dengan cara membolos, mengingkari status orang tua dengan cara minggat dari rumah atau membantah perintah mereka dan sebagainya.

Pada usia mereka memang perilaku mereka belum melanggar hukum karena yang dilanggar adalah status-status dalam lingkungan primer (keluarga) dan sekunder (sekolah) yang memang tidak diatur oleh hukuk secara terinci. Tetapi, jika remaja itu dewasa, pelanggaran status ini dapat dilakukan terhadap atasannya di kantor atau petugas hukum di masyarakat. Sementara itu, Y. Bambang Mulyono (2001: 22) membagi kenakalan remaja dibagi ke dalam dua jenis yaitu (1) Bersifat amoral dan antisosial atau kenakalan yang tidak 
melanggar hukum. Contohnya memutarbalikkan kenyataan dengan tujuan menipu orang lain atau menutup kesalahan, membolos sekolah, meninggalkan rumah orang tua atau menentang keinginan orang tua, keluyuran, bergaul dengan teman yang memberi pengaruh buruk, berpesta semalam suntuk tanpa pengawasan, membaca buku-buku cabul dan kebiasaan menggunakan bahasa yang tidak sopan atau tidak senonoh, berpakain tidak pantas sehingga dapat mengundang kemaksiatan yang dapat merugikan dirinya sendiri, (2) Kenakalan yang melanggar hukum dan mengarah kepada tindakan kriminal. Contohnya berjudi sampai menggunakan uang taruhan benda lain, mencuri, mencopet, menjambret, penipuan dan pemalsuan, pelanggaran tata susila, menjual film-film porno, pemerkosaan, pembunuhan, pengguguran kandungan dan penganiayaan berat yang mengakibatkan kematian seseorang.

Kenakalan remaja melakukan aktivitas menghirup lem (inhalen)ini ternyata juga sampai ke daerah pedesaan seperti desa yang berbatasan dengan kota Pekanbaru ibukota Propinsi Riau. Gaya hidup dan suasana kota terbawa dalam kehidupan masyarakat di daerah ini. Daerah perbatasan antara kota dan desa seperti desa Kualu Nenas Kabupaten Kampar memiliki karakteristik unik. Secara geografis desa ini berada dilintas jalan raya antara Kota Pekanbaru dan Kabupaten Kampar, dengan jarak tempuh dari pusat kota 37 menit. Hal ini dikarenakan Desa Kualu Nenas Kabupaten Kampar tidak terlalu jauh dari kota Pekanbaru ( berjarak tempuh lebih kurang 37 menit dari pusat kota propinsi).

Data dari kantor desa Kualu Nenas Februari 2017 menunjukkan jumlah remaja berusia 13-18 tahun g mencapai 668 jiwa (18\%) dari 3704 total penduduk di desa Kualu Nenas. Data tahun 2016 (Kantor Desa Kualu Nenas) mencatat bahwa remaja yang melanjutkan pendidikan sampai ke perguruan tinggi di desa tersebut hanya berjumlah 57 orang (S1-S3) dan 36 orang (D1-D3), dimana keseluruhannya baru mencapai 14\%. Artinya banyak remaja di desa Kualu Nenas yang tidak melanjutkan pendidikan sampai ke tingkat perguruan tinggi.Hasil kegiatan pengabdian berbasis riset Nurhasanah Bachtiar (2017), tentang jenis tingkah laku remaja yang paling mengkhawatirkan bagi orang tua di desa Kualu Nenas salah satunya yaitu menghirup lem.

Survey melalui wawancara dengan petugas desa diketahui bahwa belum ada regulasi yang mengatur penjualan lem bagi anak dan remaja, sehingga anak dan remaja dapat membeli lem untuk perilaku menyimpang itu. Orang tua yang sibuk dengan aktivitas mereka di kebun menyebabkan mereka tidak peduli dan mengangap tidak ada permasalahan dengan remajanya. Untuk itu perlu dilakukan pendampingan orang tua untuk mengatasi 
kebiasaan remaja mereka yang mengisap lem.Masalah yang ingin dideskripsikan dalam tulisan ini adalah proses pendampingan orang tua terhadap remaja "menghirup lem" khususnya di desa Kualu Nenas.

\section{METODE PENELITIAN}

Kegiatan pengabdian berbasis riset ini menggunakan metode participatory action research (PAR). Metode PAR tidak hanya melibatkan objek langsung yaitu orang tua anak yang inhalen, tetapi juga melibatkan pihak-pihak yang relevan (stakeholders) dalam hal ini kepala desa Kualu Nenas untuk secara aktif mengkaji masalah yang terjadi dari perspektif sendiri agar dapat dilakukan perubahan.Kegiatan penelitian dimulai dengan pengumpulan data dan dilanjutkan dengan action pendampingan orang tua dari anak yang berperilaku menghirup lem. Objek penelitian adalah orang tua di desa Kualu Nenas Pekanbaru yang direkomendasikan petugas kantor desa memiliki anak berperilaku inhalen. Pengumpulan data dengan wawancara mendalam pada orang tua tentang perilaku inhalen anak, efek samping dan penanganan yang dilakukan orang tua. Wawancara juga dilakukan pada petugas kantor desa tentang kebijakan menghirup lem. Kegiatan selanjutnya adalah pendampingan orang tua dengan mensosialisasikan dampak perilaku inhalen dan cara orang tua menangani anak.

\section{HASIL DAN DISKUSI}

Temuan penelitian dari hasil wawancara dengan orang tua yang memiliki anak menghirup lem, sebanyak dua orang diketahui bahwabelum ada kepedulian dan orang tua menganggap kecil kebiasaan remaja menghirup lem. Mereka baru merasa malu pada perilaku anaknya yang terlibat kriminal sebagai akibat perilaku menghirup lem. Mereka cenderung menutup akses untuk diwawancara lebih lanjut ketika terkait dengan tindakan kriminal anaknya.

Orang tua sesungguhnya harus memberikan kemudahan bagi peneliti untuk mencari faktor penyebab dan solusi bagi perilaku anaknya yang menghirup lem. Mereka belum menyadari akibat buruk dari kebiasaan remajanya menghirup lem. Ungkapan ini disampaikan Ibu A “ Saya tidak tau kalau anak saya menghirup lem itu berbahaya. Anak saya meminta uang jajan, dan tidak ada hal yang mencurigakan dari benda yang dibelinya. Dia tidak membeli minuman keras atau narkoba. Dia nyaman di rumah temannya setelah 
pulang sekolah". Sementara informasi yang diperoleh peneliti dari tetangga bahwa "Y sering membeli lem di toko bangungan dengan teman-tamannya."

Setelah menelusuri toko tempat terjadinya transaksi jual beli lem, diperoleh informasi bahwa memang ada beberapa anak yang sering membeli lem jenis cap kambing yang harganya berkisar tujuah ribuan. Perilaku anak yang sudah menghirup lem itu dikenali oleh masyarakat dengan gejala antara lain pendiam, kurang bergaul, emosi tinggi dan sering menyendiri dari pergaulan anak seusia mereka. Hal ini diperkuat oleh pendapat kepala desa Kualu Nenas dari hasil observasinya selama menjadi pimpinan di desa tersebut.

Faktor penyebab anak menghirup lem dari hasil wawancara dengan kepala desa adalah orang tua yang bercerai, orang tua yang memberikan kebebasan kepada anak dan tidak adanya ketenangan dirasakan oleh anak di rumah. Anak merasa mendapatkan kepuasan dengan menghirup lem sehingga mereka menjadi ketagihan. Hal ini sesuai dengan pendapat Saherodji bahwa kecendrungan kejahatan dilakukan individu adalah (1) Faktor intern yaitu faktor yang berasal dari dalam diri si pelaku itu sendiri, misalnya kurangnya disiplin diri, kurangnya kepercayaan terhadap agama, agar ia bisa diterima di lingkungan pergaulan dan bisa juga si pelaku merasa frustasi, (2) Faktor ekstern yaitu faktor yang berasal dari luar diri si pelaku itu sendiri, misalnya keadaan lingkungan sekitarnya dan masih mencari perhatian dari orang-orang yang berada di sekelilingnya, (3) Faktor lingkungan yang kurang baik dari si pelaku, (4) Perubahan pola konsumsi dari masyarakat yaitu adanya keinginan dari masyarakat untuk mengkonsumsi barang-barang secara berlebihan melebihi kemampuan finansialnya, (5) Faktor sosial.

Hal ini sesuai dengan pendapat Mudjiran, (2007: 179) yang mengemukakan banyak faktor atau kondisi remaja menjadi nakal, baik itu faktor dari dalam diri remaja itu sendiri maupun dari luar dirinya. Penelitian telah menunjukkan bahwa anak-anak yang berasal dari keluarga yang sering bertengkar ternyata lebih banyak mengalami masalah bila dibandingkan dengan kelurga yang harmonis. Uraian tentang ciri-ciri remaja ini menjadi dasar logis mengapa ada remaja yang menghirup lem.

Realitanya tidak setiap saat orang tua memberikan uang bagi anak untuk membeli lem. Akibatnya anak melakukan tindakan kriminal seperti mencuri ayam dan buah-buahan yang ada di kebun milik orang lain. Akibat yang lebih parah adalah anak yang menghirup lem kecenderungan menjadi pengguna narkoba. Data dari aparat desa di tahun 2018 telah ditangkap sebanyak 5 orang remaja Desa Kualu Nenas untuk direhabilitasi di rumah sakit akibat narkoba. 
Hal ini sangat meresahkan masyarakat. Oleh sebab itu aparat desa dalam setiap kesempatan seperti kegiatan wirid di mesjid, pertemuan adat, melakukan sosialisasi bahaya menghirup lem dan narkoba. Namun upaya itu belum dikoordinir dan dirancang secara sistemik untuk kasus anak penghirup lem. Belum ada penanganan individual dari aparat desa terhadap orang tua yang memiliki anak yang menghirup lem.

Untuk itu tim peneliti mendatangi orang tua yang memiliki anak penghirup lem sesuai dengan rekomendasi aparat desa. Setelah didekati secara individual dan persuasif, orang tua menerima informasi tentang akibat perilaku anak menghirup lem. Mereka menyadari arti penting kepedulian mereka terhadap anak dan upaya mengatasi perilaku menghirup lem.

Proses pembimbingan orang tua anak yang menghirup lem, dilakukan dengan metode diskusi personal yang berisi teknik intervensi pada anak yang menghirup lem yang ditekankan pada informasi kesehatan dan hukum serta norma agama. Orang tua diberikan pengetahun tentang cara berkomunikasi dengan anak dan membuat anak merasa nyaman di rumah sendiri.

Pembimbingan pada orang tua ini penting, karena orang tualah yang paling dekat dengan remaja dan yang memberikan pendidikan yang paling utama semenjak kelahirannya. Hal ini sesuai dengan pendapat Syamsu Yusuf (2008: 213) bahwa orang tua perlu memberikan informasi pada anak tentang bahayanya menghirup lem yang dikaitkan dengan ilmu kesehatan dan hukumnya menurut agama. Terkait dengan itu Karimis (dalam Padang Ekspres, 2009: 17) mengemukakan beberapa upaya yang dapat dilakukan orang tua untuk mengatasi perilaku menghirup lem remaja adalah (1)Menjadikan rumah sebagai lembaga pendidikan pertama bagi anak dan tidak menyerahkan sepenuhnya pada pendidikan sekolah dan lingkungan. orang tua perlu terlibat aktif dalam membentuk akhlak anak dengan memberi pembinaan budi pekerti dan spiritual (agama), (2) Orang tua menjadikan dirinya sebagai tokoh panutan yang dapat dicontoh dan ditiru sehingga remaja tidak salah meniru. Bila orang tua tidak dapat dijadikan tokoh panutan maka anak akan mencari tokoh panutan di luar rumah yang berpeluang besar mangarahkan anak pada kenakalan, (3) Orang tua perlu aktif memantau dan mengawasi perilaku anak di luar rumah dan mengarahkan dalam mencari teman yang baik agar anak-anak tidak terjerumus dengan teman-teman yang kurang baik, (4) Mengarahkan anak pada pergaulan yang bersifat religius misalnya remaja mesjid agar semua aktivitasnya mengarah kepada aktivitas sosial dan keagamaan, (5) Orang tua mengarahkan pengguanaan waktu anaknya terutama waktu luang agar waktu anaka 
tidak terbuang menjadi sia-sia. Penggunaan waktu luang yang tidak terarah merupakan sebab dominan dalam kenakalan, (5) Kenakalan remaja banyak bersumber dari pergaulan, oleh karena itu, orang tua hendaknya dapat memberikan inti pendidikan terhadap anak. Inti pendidikan adalah sebuah pedoman dasar pergaulan yang singkat, padat dan mudah didingat serta dilaksanakan sehingga anak menjadi mandiri dan dapat dipercaya, (6)Adanya kemauan orang tua untuk membenahi kondisi lingkungan keluarga sehingga tercipta keluarga yang harmonis, komunikatif dan nyaman bagi remaja.

Soedjono Dirdjosisworo (dalam Sudarsono, 1990: 93) mengemukakan cara penanggulangan kenakalan remaja dapat dilakukan secara moralistik maupun secara abolisionistik. Secara moralistik maksudnya diadakan pembinaan moral dan kekuatan mental remaja. Dengan pembinaan moral yang baik remaja tidak akan mudah terjerumus ke dalam perbuatan-perbuatan nakal sebab nilai-nilai moral tadi akan mampu menggagalkannya dan mejauhkan diri dari perbuatan-perbuatan nakal. Sedangkan cara abolisionistik adalah cara untuk mengurangi bahkan untuk menghilangkan sebab-sebab yang mendorong remaja melakukan perbuatan nakal dengan motif apa saja. Disamping itu, yang tidak kalah pentingnya adalah usaha untuk memperkecil bahkan meniadakan faktorfaktor yang membuat remaja terjerumus dalam perbuatan nakal.

Selanjutnya, Bimo Walgito (1972: 20) mengemukakan beberapa usaha yng dapat dilakukan orang tua untuk mengatasi kenakalan remaja adalah (1) Memahami dan mengerti dengan kebutuhan-kebutuhan anaknya yang bukan hanya kebutuhan biologis seperti makan, minum, pakaian, dan sebagainya. Melainkan juga kebutuhan psikologis seperti kebutuhan cinta dan kasih sayang dari orang lain terutama dari orang tua, kebutuhan rasa aman, mendapatkan keadilan dan sebagainya. Orang tua sangat salah apabila mereka berpendapat bahwa hanya kebutuhan biologis saja yang dibutuhkan oleh anak-anaknya. Asal sudah makan baik, pakaian baik dan sebagainya adalah sudah cukup, (2) Menciptakan suasan keluarga sebaik mungkin dan menghindari percekcokan antara orang tua dan anggota keluarga yang lainnya untuk menghindari terjadinya broken home baik yang semu maupun yang sebenarnya, (3) Tanamkan disiplin pada anak semenjak usia dini sehingga nantinya menjadi kebiasaan. Cara menanamkan disipilin ini misalnya dengan memberikan tugas tertentu yang tujuannya memang untuk menciptakan disiplin anak, (4) Mengadakan pengawasan terhadap kegiatan anak terutamam mengenai keadaan dalam kelompok teman sebaya karena kelompok teman sebaya sangat mempengaruhi tingkah laku remaja, (5) Mengarahkan anak pada pengisian waktu luang dengan kegiatan yang bermanfaat misalnya 
derngan olahraga, kegiatan kesenian, membaca bacaaan yang bermanfaat dan sebagainya, (6) Menciptakan kesatuan norma sehingga tidak membingungkan anak. Jika tidak adanya kesatuam norma antara ayah dan ibu misalnya ayah memperbolehkan anak memakai rok mini sedangkan ibu sangat melarang maka hal ini akan sangat membingungkan anak.

Simandjuntak (1975: 175) mengemukakan bahwa orang tua harus mengerti pribadi dan minat setiap anak yang berbeda antara yang satu dengan yang lainnya. Oleh karena itu, orang tua harus mendapatkan kepercayaan anak sebagai teman agar anak mau menceritakan segala kesulitan dan tekanan batinnya secara terbuka. Dan itu semua dapat terlaksana apabila orang tua telah memberikan kasih sayang yang seutuhnya kapada anak. Penelitian para ahli telah membuktikan bahwa anak-anak yang sejak kecil memperoleh pemeliharaan berdasarkan kasih sayang dan kemesraan maka akan tumbuh menjadi pribadi yang stabil. Sedangkan anak-anak yanmg tidak pernah merasakan kasih saying akan bertingkah laku antisosial.

Y. Bambang Mulyono (2001: 54) menyatakan beberapa hal yang harus dilakukan orang tua adalah ; berusaha mengerti pribadi anak-anaknya, memupuk kesanggupan anak untuk menolong diri sendiri dalam menghadapi masalah, mengembangkan potensi atau bakat anak, membimbing anak untuk mampu menyesuaikan diri terhadap lingkungan sekitarnya dan membimbing anak pada ketaatan dan nilai-nilai agama dan moral.

Ki Sakti Slamet (1991: 18) menyatakan salah satu cara yang dapat mengatasi kenakalan remaja adalah mengajarkan anak-anak pada nilai-nilai agama yang membawa anak didik ke arah pembentukan akhlak dan akal. Tidak hanya dalam bentuk ceramah atau dakwah tetapi harus dalam bentuk penjabaran sehingga dapat dirasakan dan dicernakan kegunaannya.Sementara itu, beberapa model yang disarankan oleh Djadjuliyanto (1995: 173-175) untuk mengatasi kenakalan remaja adalah denganmenciptakan kondisi yang dapat menimbulkan kesenangan dan kebahagiaan dalam keluarga,berikan latihan bertanggung jawab pada anak dan berikan latihan untuk berempati. Sedangkan Soetarlinah Soekardji (dalam Djadjuliyanto, 1995: 175) menyatakan cara yang dapat dilakukan orang tua adalah dengan menciptakan komunikasi yang baik, menjadi suri teladan, menciptakan rasa bahagia, menghormati nilai-nilai luhur melalui tindakan maupun perbuatan dan membimbing pada ajaran agama.

Dengan demikian dapat disimpulkan bahwa yang paling penting dilakukan oran tua untuk menyelamatkan putra dan putrinya dari kanakalan remaja adalah dengan memberikan perhatian, kasih sayang yang tulus dan pemberian atau pembekalan nilai-nilai agama 
sehingga dimanapun anak berada akan menimbulkan rasa malu, takut dan cemas pada dirinya sendiri ketika akan melakukan kenakalan. Bila hal tersebut telah dilakukan semoga para generasi kita akan menjadi generasi yang bermanfaat bagi dirinya sendiri dan orangorang yang berada di sekitarnya.

Hasil pendampingan terhadap orang tua yang dievaluasi selama dua minggu, diketahui bahwa terjadi perubahan tingkah laku orang tua terhadap anak. Menurut orang tua, anak mereka lebih sering di rumah dibandingkan dengan sebelumnya. Temuan ini menunjukkan bahwa pendampingan berhasil meningkatkan peran orang tua dalam meminimalisir perilaku anak untuk menghirup lem.

\section{KESIMPULAN}

Perilaku menghirup lem adalah perilaku menyimpang remaja yang harus dipedulikan oleh orang tua. Inhalen atau menghirup lem berdampak negatif bagi kesehatan fisik dan psikologis remaja serta dapat memicu remaja mendekati narkoba. Orang tua harus menyediakan waktu dan perhatiannya pada perilaku remaja, yang dapat memicu terjadinya penyimpangan. Pendampingan orang tua yang belum peduli pada perilaku menyimpang anaknya melakukan inhalen, adalah dengan berdiskusi dan melatih orang tua bersikap yang tepat agar remaja mereka berhenti menghirup lem. Tindakan ini tidak akan berhasil jika tidak dibarengi dengan regulasi dari pemerintah dan kepedulian masyarakat. Kepedulian masyarakat seperti penjual lem dan aparat desa diharapkan, agar remaja dapat menghentikan perilaku menghirup lem. Kerjasama semua pihak diharapkan agar terwujud remaja yang sehat sebagai generasi penerus bangsa.

\section{DAFTAR PUSTAKA}

Bimo Walgito. 1972. Juvenile Delinquency (Kenakalan Anak). Yogyakarta: JASBITPSY UGM.

Djadjuliyanto. 1995. Masalab Penanggulangan dan Pembinaan Kenakalan Remaja. Jakarta: Ariesta Printing.

Elida Prayitno. 2006. Psikologi Perkembangan Remaja. Padang: Angkasa Raya.

Elizabeth B. Horlock. 1991. Psikologi Perkembangan. Jakarta: Erlangga.

H.Hari Saherodji, 1995. Pokok-Pokok Kriminologi, Aksara Baru, Jakarta, 1995, hal. 36. 
Karimis. 2009. 20 Januari. Kenakalan Remaja dan Upaya Mengatasinnya. Padang Ekspres, hlm. 17

Kartini Kartono. 1991a. Bimbingan bagi Anak dan Remaja yang Bermasalah. Jakarta: CV Rajawali.

Kartini Kartono. 2006b. Patologi Sosial 2 Kenakalan Remaja. Jakarta: Grafindo Persada.

Ki Sakti Slamet. 1991. Perbatian, Kasih Sayang Guru dan Orang Tua Panutan Penangkal Kenakalan Remaja. Jakarta: Departemen Penerangan dan Penerbitan Mass Media.

Mudjiran. 2007. Perkembangan Peserta Didik. Padang: UNP.

Mulyana W. Fususmah. 1982. Analisa Kriminologi tentang Kejahatan-Kejahatan Kekerasan. Jakarta: Ghalia Indonesia.

Ninik Widiyanti. 1987. Kejahatan dalam Masyarakat dan Pencegahannya. Jakarta: Bima Aksara.

Pebrinaldi Sangir. 2009. Stres Remaja. KabarIndonesia, (Online), Vol. 1, No. I. (http://www.kabarindonesia.com/berita, diakses 23 Mei 2009)

S.W. Sarwono. 2001. Psikologi Perkembangan Remaja. Jakarta: PT Raja Grafindo Persada.

Santrock. 2003. Life Span Development. Jakarta: Eralangga.

Simanjutak. 1975. Latar Belakang Kenakalan Remaja. Bandung: Penerbit Alumni.

Singgih D. Gunarso. 1988. Psikologi Remaja. Jakarta: Gunung Mulia.

Soesilowindradini. 1990. Psikologi Perkembangan Masa Remaja. Surabaya: Usaha Nasional.

Sudarsono. 1990. Kenakalan Remaja. Jakarta. Rineka Cipta.

Sutaat. 2012. Pemberdayaan Masyarakat Daerah Perbatasan Antar Negara; Studi Masalah, Kebutuhan dan Sumber Daya Sosial Desa Jagoi, Kecamatan Jagoi Babang Kabupaten Bengkayang, Kalimantan Barat. Sosiokonsepsia Vol. 17, No. 012012. https://puslit.kemsos.go.id/upload/post/files/de61f2970a85f3e92daf9cfd7a43cb e9.pdf

Agus afandi, dkk,. 2013. Modul Participatory Action Reseacrh (PAR) (IAIN Sunan Ampel Surabaya: Lembaga Pengabdian Masyarakat (LPM) Hal. 41 